\title{
NIE BYĆ DRAPIEŻNIKIEM?
}

\author{
Marta Bucholc \\ Uniwersytet Warszawski
}

Agata Lukomska

Uniwersytet Warszawski

Pojęcie tożsamości ma w naszym języku pozytywne konotacje. Mówimy o „silnej tożsamości” lokalnej, regionalnej czy narodowej, o „odkrywaniu swojej tożsamości” w procesie dojrzewania, o „wyrażaniu własnej tożsamości” w relacjach międzyludzkich, o „kształtowaniu się tożsamości” w wyniku rozmaitych doświadczeń i ,zachowywaniu odrębnej tożsamości” wbrew naporowi tychże. Naturalnie niekiedy okazuje się, że tożsamość jest źródłem konfliktów, przyczyną cierpienia zarówno jej podmiotu, jak i całego otoczenia. Z pewnościa dla wielu czasami lepiej byłoby, aby dana tożsamość była inna. Posiadanie tożsamości jako takie jest jednak nieodmiennie oceniane dodatnio, o czym świadczy zupełnie niedwuznaczny wydźwięk takich wyrażeń jak „budowanie tożsamości” czy „zanik” albo wręcz „rozpad tożsamości”. To domyślnie pozytywne nacechowanie pojęcia tożsamości jest samo w sobie argumentem na rzecz tezy, iż dominacja paradygmatu tożsamości w badaniach nad innością toruje drogę do „tyranii tożsamości” (zob. Czerniawska 2008).

Ryzyko związane z bezkrytycznie dodatnim postrzeganiem tożsamości staje się oczywiste, gdy tylko przeniesiemy się na grunt badań tożsamości zbiorowych. Punktem wyjścia do oszacowania tego ryzyka jest neutralne określenie tożsamości jako pojęcia „relacyjnego” - tożsamość można mieć tylko wobec i względem kogoś, kto nie jest nami. Co to znaczy w świecie społecznym? To, że każde „my” i każde „poczucie my” odzwierciedlające wykształcenie się tożsamości grupowej może zaistnieć jedynie na gruncie 
uznania, że ktoś do owego „my” nie należy - nie jest „swój”, bo nie jest taki jak my. Tożsamość implikuje zatem inność. Inność zaś uruchamia zupełnie inny ciąg skojarzeń i działań. Jak pisze Magdalena Środa w książce Obcy, inny, wykluczony (2020: 6):

Obcość to nie tylko rewers „naszości” - obcy to zagrożenie. Wykluczeni ze społeczności, dehumanizowani, odarci z praw obcy nie budzą litości, lecz strach. Mają różne twarze, najczęściej terrorysty, złodzieja, dziwaka (queer), spiskowca lub - jak mówi za Bertoldem Brechtem Zygmunt Bauman - „posłańca złych wiadomości”, czyli kogoś, kto przypomina nam o kruchości naszego stabilnego życia.

Obcy powoływany do istnienia w procesie budowania naszej grupowej tożsamości to zupełnie inny obcy niż „przybysz, który zostaje” Georga Simmla - zdystansowany, obiektywny arbiter, którego - owszem - notorycznie dyskryminujemy podatkowo wskutek rodzajowego postrzegania, ale którego potrzebujemy w „naszych” społeczeństwach - i dobrze o tym wiemy (Simmel 1975). To też zupełnie inny obcy niż Obcy z. wyboru, o którym pisał Andrzej Waśkiewicz, iż nie należy on do żadnej społecznej kategorii, bo jego ojczyzna „nie jest z tego świata” (2008: 9). To obcy postrzegany jako groźny i szkodliwy, obcy, który nie ma prawa do żadnej ojczyzny. Nie jest on wykluczony siłą rzeczy przez to, że jest zbędny, co już byłoby dostatecznie bolesne. Jest aktywnie zwalczany, aż do anihilacji - tylko bowiem wykluczenie obcego przez unicestwienie go (fizyczne lub symboliczne) daje gwarancję ontologicznego bezpieczeństwa „my”.

Tożsamości, które dla swego zabezpieczenia wymagaja aż tak radykalnej eliminacji obcego, Arjun Appadurai określił jako „drapieżne”. Ich „tworzenie i mobilizacja wymagaja zagłady innych, zbliżonych kategorii społecznych, zdefiniowanych jako zagrożenia dla samego istnienia grupy zdefiniowanej jako my" (Appadurai 2009: 57). Drapieżna tożsamość, odnosząc się do inności, skazuje ją zarazem na unicestwienie. Amerykański antropolog jako jeden z podstawowych mechanizmów prowadzących do przemiany niegroźnej tożsamości społecznej w drapieżna wskazuje mobilizację postrzegania własnej grupy jako zagrożonej większości, przejaw prześladującego współczesny świat lęku przed małymi liczbami.

Autorzy tekstów, które złożyły się na niniejszy numer „Stanu Rzeczy”, pochylaja się nad warunkami i mechanizmami powstawania drapieżnych tożsamości. Według Michała Nawrockiego proces ten można lepiej zrozumieć dzięki analizie strategii politycznego populizmu, któremu - niezależ- 
nie od tego, czy jest to populizm prawicowy, czy lewicowy - przyświeca ideał czystości i ontologicznej kompletności suwerennego ludu. Warunkiem uczestnictwa w tym projekcie jest, jak pisze Nawrocki, tyleż komunizacja - przekroczenie ograniczeń jednostkowej perspektywy i otwarcie się na pozostałych członków wspólnoty - ile immunizacja: zamknięcie się, a raczej nieustanne zamykanie się, przed obcym, który jedności wspólnoty zagraża. Proces ten nie musi oczywiście dotyczyć wspólnot narodowych - w kolejnym artykule numeru Radosław Kossakowski analizuje jego przebieg na przykładzie fascynującej historii ruchu kibicowskiego w Polsce.

Drapieżną tożsamość buduje się dzięki identyfikowaniu zewnętrznego i wewnętrznego wroga. Marta Rawłuszko zastanawia się, dlaczego współcześnie tak często kryterium jest płciowa i seksualna różnica. Analizując polskie spory wokół feminizmu i ,ideologii LGBT”, zadaje pytanie o to, na ile odpowiadają za nie wewnętrzne napięcia hierarchii płci, na ile zaś społeczny gniew o podłożu przede wszystkim ekonomicznym, dla którego mniejszości nieheteronormatywne okazuja się dogodnym celem zastępczym. Z kolei Łukasz Rozwadowski interpretuje spory o gender jako wyraz lęku przed utratą indywidualnej tożsamości, uniformizacją i w ostatecznej perspektywie - totalitaryzmem. Jak przekonuje, kieruja się nim zarówno fanatyczni antygenderyści, jak i namiętni genderyści.

Wiele wskazuje na to, że do uruchomienia mechanizmów kształtowania się drapieżnej tożsamości potrzebne są przy tym szczególne warunki, zwłaszcza jeśli chodzi o technologię i kulturę przekazywania informacji. Urszula Jarecka i Paweł Fortuna piszą o procesach kształtowania się „tożsamości cyfrowych" oraz o sposobach, w jakie modele interakcji w sieci rzutują na nasze praktyki poza nią. Zwracają przy tym uwagę na złożone powody, dla których komunikacja za pomoca Internetu sprzyja powstawaniu i pogłębianiu się nieufności, wrogości i agresji. Materiału poglądowego dostarcza Jan Radomski, opisujący „strategię wyciszania”, jaką jego zdaniem prawicowi publicyści stosują, w sieci i poza nią, wobec szwedzkiej aktywistki Grety Thunberg. Kluczowym elementem tej strategii okazuje się definiowanie tożsamości atakowanego podmiotu jako na różne sposoby obcej w stosunku do zagrożonej i bronionej wspólnoty.

„Drapieżność” nie musi być jednak skierowana przeciwko ludzkiemu obcemu. W ostatniej z rozpraw, jakie publikujemy w tym numerze, Marek Krajewski opisuje zjawisko biofobii, rozumianej jako dążenie do określenia naszej ludzkiej tożsamości w kontrze do nieuporządkowanej, chaotycznej natury. Zadaje przy tym pytanie, czy jej przeciwieństwo - biofilia - nie jest 
naszą najlepszą szansą na znalezienie drogi do przezwyciężania podziałów nękających ludzką wspólnotę.

Jako tło do zrozumienia niektórych źródeł drapieżności publikujemy nietłumaczony dotąd na język polski tekst Hansa Joasa, poświęcony zagadnieniu sakralizacji władzy. W tej syntetycznej prezentacji problematyki historycznych związków religii z władzą niemiecki socjolog broni uniwersalizmu religii światowych i - krytykując utożsamienie europejskości z chrześcijaństwem - przeciwstawia się „myleniu swoistych cech kulturowych z uniwersalistycznym przesłaniem", które dostarcza podstaw roszczeń do kulturowej wyższości i wynikającej z niej politycznej dominacji. Teza Joasa głosi, że religie światowe wciąż na nowo są narażane na pokusę związania swego losu z władza polityczną, ale szanse na zachowanie ich uniwersalistycznego przesłania zależą od tego, na ile skutecznie zdołaja się tej pokusie oprzeć. Wprowadzenie Michała Kaczmarczyka, tłumacza Powstawania wartości pióra Joasa (2009), sytuuje rozważania nad sakralizacja władzy na tle szerszego przeglądu teorii tego autora, należącego do najbardziej wpływowych współczesnych niemieckich socjologów.

W numerze tym prezentujemy również przeprowadzony przez Michała Luczewskiego wywiad z Anną Gizą-Poleszczuk, Dziekan Wydziału Socjologii Uniwersytetu Warszawskiego, oraz Michaelem D. Kennedym, profesorem Uniwersytetu Browna, poświęcony jakże aktualnemu zagadnieniu szczęścia w pracy akademickiej. Rozmówcy Łuczewskiego podają wprawdzie przygnębiająco wiele przykładów drapieżności w środowisku akademickim, ale namawiają nas też, byśmy nie zarzucali dążenia do szczęścia jako przedsięwzięcia opartego na współdziałaniu i wzajemnej akceptacji.

Z kolei w dziale recenzji publikujemy tekst Marty Bucholc poświęcony wspomnianej już książce Magdaleny Środy Obcy, inny, wykluczony, będacej jednym ze źródeł inspiracji tego numeru, Michała Rauszera recenzję książki Jaśminy Korczak-Siedleckiej Prz̧emoc $i$ honor w życiu społecznym wsi na Mierzei Wiślanej w XVI-XVII wieku, oraz rozważania Tomasza Maślanki wokół książki Andrzeja Waśkiewicza Ludzie - rz̨eczy - ludzie. O porz̨adkach spotecznych, w których rzeczy tacza, a nie driela.

Bibliografia:

/// Appadurai A. 2009. Strach præeed mniejszościami. Esej o geografii gniewu, tłum. M. Bucholc, Wydawnictwo Naukowe PWN. 
/// Czarniawska B. 2008. Alterity/Identity Interplay in Image Construction, [w:] The Sage Handbook of New Approaches in Management and Organization, red. D. Barry, H. Hansen, Sage, s. 49-62.

/// Simmel G. 1975. Obcy, [w:] tegoż, Socjologia, tłum. M. Łukasiewicz, Państwowe Wydawnictwo Naukowe, s. 504-512.

/// Środa M. 2020. Obcy, inny, wyleluczony, słowo/obraz terytoria.

/// Waśkiewicz A. 2008. Obcy z wyboru: studium filozofii aspotecznej, Prószyński i S-ka.

/// Marta Bucholc - profesor uczelni na Wydziale Socjologii Uniwersytetu Warszawskiego, chercheuse associée w Centre de recherche en science politique na Uniwersytecie Saint-Louis w Brukseli. Kieruje na WS UW finansowanym przez NCN projektem SONATA Bis pod tytułem „Kształtowanie się habitusu narodowego a proces cywilizacji w Polsce po roku 1989” oraz polską częścia projektu finansowanego przez Fundację Volkswagena zatytułowanym „Towards Illiberal Constitutionalism in East Central Europe”. Ostatnie publikacje autorki to: The Established and the Outsiders in the AntiLGBTI Campaign in Poland: Legal Performance of Exclusion, „Law \& Policy” (w druku); Law and Liberal Pedagogy in a Post-Socialist Society: The Case of Poland, "Journal of Modern European History" 18, 2020, nr 3, s. 324-334; Schengen and the Rosary. Catholic Religion and the Postcolonial Syndrome in Polish National Habitus, „Historical Social Research” 45, 2020, nr 1, s. 153-181.

ORCID: https://orcid.org/0000-0002-1874-2024

E-mail: m.bucholc@uw.edu.pl

/// Agata Lukomska - adiunktka w Zakładzie Etyki Wydziału Filozofii Uniwersytetu Warszawskiego. Ostatnia publikacja autorki to artykuł Confidence. On the Possibility of Ethical Knowledge, [w:] Morality and Agency: Themes from Bernard Williams, red. A. Szigeti, M. Talbert, New York: Oxford University Press, 2021 (w druku).

ORCID: https://orcid.org/0000-0001-7537-7097

E-mail: agata.lukomska@uw.edu.pl 